\title{
ESTILO E REGRESSÃO EM POESIAS (1956): A DICÇÃO INFANTILIZADA EM MANOEL DE \\ BARROS
}

\author{
Edson Soares MARTINS*
}

A

poesia de Manoel de Barros possui um caráter fortemente evolutivo. Talvez o traço mais evidente desta característica seja o reaproveitamento de temas, o realimentar-se autofágico da poesia barrosiana, em que um título de poema ou um verso retomado dão origem a outros poemas e outros livros. Não se pretende desenvolver aqui uma análise deste procedimento da genética barrosiana. Interessa-nos um outro aspecto, menos visível, embora igualmente indicador da evolução permanente da poesia de Manoel de Barros, a despeito das resenhas ranzinzas que surgem a cada título lançado pelo poeta $\mathrm{e}$ que, sem muita diferença entre si, "descobrem o esgotamento" da originalidade de Barros.

Determinado a seguir os caminhos e atalhos de uma demanda regressiva, como será demonstrado adiante, Barros utiliza já nos primeiros livros (Poemas concebidos sem Pecado e Face Imóvel)' o recurso que consiste em dividir internamente suas obras em "séries temáticas", com poemas numerados e a que

* Universidade do Tocantins - Unitins, Campus de Tocantinópolis.

1 BARROS, M. de. Gramática expositiva do chão: (poesia quase toda). 3. ed. Rio de Janeiro: Civilização Brasileira, 1996. Todos os poemas citados deste livro serão indicados apenas pelo número da página, logo após a transcrição e entre parênteses. 
MARTINS, E. S. Estilo e regressão em Poesias (1956):...

ele retornará obsessivamente nos livros seguintes. Isto permite analisar o conjunto tendo como apoio a percepção de que há uma única voz lírica ao longo dos vários poemas.

Esta uniformidade de representação da subjetividade corresponde, no plano do discurso poético, à construção de uma ausência: na grande maioria dos poemas, dificilmente se encontram marcas, exceto nos títulos das séries, que permitam reconstituir a referência contextual do eu-lírico.

Esta referência contextual se estabeleceria, nessa análise, sempre que o poema remetesse à situação do eu-lírico no momento da enunciação. A consideração da prostituição, através do trabalho da memória, revela, por exemplo, o contexto de um sujeito-enunciador distanciado de um objeto que lhe causara prazer e culpa. ${ }^{2}$ A rememoração do relato da vida de uma pobre menina, que desperta a solidariedade e o carinho saudoso do sujeito, aponta na direção de uma apreciação crítica do passado. ${ }^{3}$ Esta apreciação crítica, que chega mesmo a conduzir o mecanismo de seleção e agrupamento dos textos, é, por exemplo, o que chamamos de referência contextual nestes primeiros livros de Manoel de Barros.

Naturalmente, esta afirmação parte primeiramente de uma observação quantitativa, o que significa que, na primeira parte deste raciocínio, consideramos a comparação entre os dois livros anteriores a 1956 e os que lhe são posteriores, tendo em conta a presença formal, observável, de elementos que, no texto, remetam ao contexto da sua enunciação. Assim, verificamos que, quantitativamente, os poemas que possuem tal referência são mais freqüentes antes de Poesias, obra de 1956, como também identifica-se um conjunto de imagens - a boca, por exemplo - sistematicamente repetidos, e que têm como ponto de origem estas três obras.

Tanto a uniformidade de representação do eu-lírico quanto à reiteração imagética assumem dimensões que participam da natureza de um mecanismo compulsivo, embora estes procedimentos, transpostos para o campo da criação estética possam ser considerados enquanto fenômeno meramente estilístico. Isto, todavia, não é impedimento suficientemente razoável para invalidar o paralelo entre compulsão e construção do "estilo". O enlace possivel ganha clareza com a consideração do conceito de regressão na teoria freudiana.

A demanda regressiva a que aludimos acima deve ser compreendida como o abandono voluntário de situações de subjetivação em que são necessá-

2 BARROS, op. cit., p. 46-55. (Ver “Antoninha-me-leva”, "Maria-pelego-preto", "Informações sobre a musa").

3 Ibid., p. 48-49. (Ver "Polina"). 
rios mecanismos mais elaborados. Colhemos em Laplanche e Pontalis ${ }^{4}$ que a regressão "é concebida, a maioria das vezes, como um retorno a formas anteriores de desenvolvimento do pensamento, das relações de objeto e da estruturação do comportamento".

Empregamos este conceito mais em seu registro temporal, no qual a regressão se dá pelo "retorno do sujeito a etapas ultrapassadas de seu desenvolvimento" (fases libidinais, relações de objeto, identificações, etc.), mas também em seu registro tópico, quando ocorre "ao longo de uma sucessão de sistemas psíquicos." 5 Um exemplo relativamente simples disto seria a situação do indivíduo que, tendo adquirido através da ameaça de castração a possibilidade de renunciar à satisfação imediata de seu desejo, pelo adiamento ou substituição, abandona o princípio de realidade e retorna ao domínio do princípio de prazer. Isto pressupõe, por sua vez, que na topologia do aparelho mental, o eu-prazer/ desprazer coexiste com o eu-realidade definitivo e com o eu-real originário - este regido pelo princípio de Nirvana.

Não há surpresa alguma nisto, já que a força pulsional é constante e que, para dominar seu impacto traumático, o corpo deverá ter diferentes níveis de organização constituídos em diversos corpos-sujeitos. Mesmo assim, não é necessário entender esta necessidade constante de remanejamento do corpo em face do impacto pulsional para postular a pertinência de uma demanda regressiva. Acrescentaremos apenas que, para Freud, o passado infantil permanece sempre em nós:

Essa extraordinária plasticidade dos desenvolvimentos mentais não se restringe ao que diz respeito à direção; pode ser descrita como uma capacidade especial para a involução - para a regressão... Contudo, as etapas primitivas sempre podem ser restabelecidas; a mente primitiva é, no sentido mais pleno desse termo, imperecivel. ${ }^{6}$

4 LAPLANCHE, J.; PONTALIS, J.-B. Vocabulário da psicanálise. 3. ed. São Paulo: Martins Fontes, 1998. p. 440.

$5 \mathrm{Id}$.

6 FREUD, S. Reflexões para os tempos de guerra e morte. In: FREUD, S. A História do movimento psicanalítico, artigos sobre metapsicologia e outros trabalhos. Rio de Janeiro: Imago, 1996. Edição Standard Brasileira das Obras Psicológicas Completas de Sigmund Freud, v. 14 , p. $282-312$. 
O aspecto da repetição compulsiva, aqui associado à uniformidade de representação do eu-lírico, também estabelecido a partir da consideração quantitativa dos elementos repetidos no texto, como estratégia de fixação do estilo, constitui um elemento que deve ser associado à demanda regressiva. Isto porque, a partir da repetição destas imagens discursivas, torna-se perceptivel um retorno a estruturações de comportamento que deveriam estar ultrapassadas. Assim, pela repetição e pela regressão, não se pode ignorar a reinscrição do passado no presente.

\section{$O$ caso da boca}

Neste caminho, toma-se como exemplar um procedimento que chama a atenção e que diz respeito a uma construção imagética vigorosamente impertinente da boca e dos vocábulos que se acham, de algum modo, ligados ao universo de significações que a boca representa na vida do homem.

Para tanto, propõe-se, partindo apenas das ocorrências verificadas em Poesias, algumas considerações.

A boca, às vezes, é vista numa situação de impertinência que traz reiteradamente a noção de vegetalidade, como no poema que segue:

8.

A boca está aberta, seca e escura

de raizes mortas...

Encontro restos de orvalho

No rosto da terra, e os bebo

Ao silêncio do enxofre que penetra

Deito-me para germinar...

Ouço fluir a seiva

Ouço o caule crescer

Do ventre que gesta sob ramas...

Uma flor de moliços depois

Irá comendo o contorno dos lábios

$\mathrm{E}$ as mãos sem despedidas.

Corpo em árvore feito 
Serei como talha de pedra

$\mathrm{Na}$ terra, com molduras de fresco

E hortensias...

Ervas tolhiças crescerão

Nos interstícios do ser

E o que foi música e sede de sarças

Há de ser pasto de águas...(p. 79-80)

O poema descreve uma espécie de transmutação biológica: a passagem da condição humana para a de árvore. Os quartetos metaforizam, respectivamente, o sulco na terra, a semeadura, a germinação, a brotação e a morte futuras, mas as marcas da primeira pessoa, disseminadas pelos verbos, revelam o discurso do desejo na transformação. Se esta quer ser metafórica ou não, pouco se pode fazer para determiná-la ou para afirmá-la. Por hora, retomemos nosso percurso.

A boca, no primeiro quarteto, pertence à terra e não ao homem. Embora o sintagma de raizes mortas não permita fácil interpretação sintática, arriscariamos dizer que se trata de um adjunto indicador de causa ou agente. É indiscutível o efeito de impertinência que ele implica. Há, assim, logo de início, uma representação impertinente da boca, pertencendo ela a um elemento sem marcas de animalidade, mas adjetivada como aberta, seca e escura. Se a estes adjetivos seria também aplicável a noção da metáfora desgastada (catacrese) boca significando fenda, o verbo estar dirime a dúvida, já que nos obriga a levar em conta o estado atual da boca como órgão, por oposição a ser boca significando fenda ou abertura. De resto, o grupo no rosto da terra torna explícito que não se trata de uma fenda a que se chamou boca, mas de uma boca a que se chamou aberta, seca e escura.

Note-se que a água, elemento vital, é encontrada e assimilada pelo eulírico, apesar da boca/órgão/fenda (boca impertinente) ser seca. Aliás, todos os elementos da isotopia da mineralidade (seca, orvalho, terra, enxofre, pedra, águas), longe de representarem esterilidade, são apresentadas numa função de fertilidade ou de fertilização. Mesmo a talha de pedra é emoldurada de frescor e de flores.

A isotopia da vida (bebo, orvalho, germinar, fluir, seiva, crescer, ventre, gesta, moliços, crescerão) é estabelecida não apenas pelos semas que seus componentes têm em comum, mas pela mesma funcionalidade: a vida é representada porque está a serviço da transformação almejada pelo discurso delirante do eu-lírico. 
A isotopia do corpo, na qual também reunem-se os verbos relacionados à existência corpórea (boca, terra, bebo, silêncio, deito, ouço [2x], ventre, gesta, comendo, lábios, mãos, corpo), além de tensionada pela transformação deseja$\mathrm{da}$, contribui, através de sucessivas impertinências, para estabelecer a dubiedade da condição biológica que o eu-lírico figura para si mesmo. Deito-me para germinar/Ouço fluir a seiva/Ouço o caule crescer/Uma flor de moliços depois / Irá comendo o contorno dos lábios / $\mathrm{E}$ as mãos sem despedida. /Corpo em árvore feito, são versos que representam essa fusão entre animalidade e vegetalidade.

A segunda ocorrência da boca está em lábios, comidos por uma flor de moliços. Convém detalhar esta imagem. Moliços são limos e outras plantas aquáticas que servem de adubo. Esta flor fertilizante e devoradora, sombra de uma vagina arquetípica, em nossa leitura, parece representar o resíduo de um processo de recalque que não foi de todo bem-sucedido. Infelizmente, na clínica psicanalítica ou na aplicação que fazemos do saber psicanalítico em outros campos do fazer humano, nem sempre é possível, depois de identificar as conseqüências, estabelecer as causas prováveis. $O$ que não nos impede totalmente de levantar algumas hipóteses. Se, neste caso, aventa-se a possibilidade de um trabalho inábil do recalque, é por coerência com as hipóteses deste trabalho, que pressupõem um percurso de involução da subjetivação do eu-lírico, indo de uma configuração mais elaborada para estados mais primitivos. Daí a idéia de que as falhas neste processo possam deixar resíduos no poema.

Mas, retornando-se, outra vez mais, à análise da boca em proximidade com a idéia de vegetalidade, na mesma sequiência de poemas encontraremos:

\author{
11. \\ Aqui: ardo e maduro. \\ Compreendo as azinheiras. \\ Compreendo a terra podre e fermentada \\ De raízes mortas.
}

Compreendo a presciência do fruto

Na carne intocada.

$\mathrm{E}$ assisto crescerem

Frescos, nessa carne, os teus dedos.

Compreendo esse garfo na terra

A germinar ferrugens

Sob laranjais... 
E o grão que semearam na pedra.

E mais: os troncos rugosos

Pendendo suas bocas para as águas. (p. 81-83)

Iniciemos pelo levantamento da isotopia da vegetalidade: maduro, azinheiras, raízes, fruto, germinar, laranjais, grão, semearam, troncos. Esta vegetalidade, também aqui, compõe um dos lados da conformação corpórea que o eu-lírico se atribui. Neste caso, entretanto, não há oposição entre vegetalidade e mineralidade (terra, garfo, ferrugens, pedra, águas) ou animalidade (carne, assisto, dedos, semearam, bocas). Todas estas isotopias dos reinos da natureza compõem uma outra isotopia maior, a da natureza englobante, com a qual o eulírico busca uma identidade corpórea. Todavia, no amplo conjunto desta isotopia da natureza englobante, dois aspectos são decisivos: o primeiro, marcado pelo advérbio isolado (Aqui) no primeiro verso do primeiro quarteto, que estabelece uma espacialidade específica e restrita. É este advérbio, no qual se fundem espaço determinado e tempo presente, que determina do alto de sua posição todo o restante do poema. O segundo, rastreado no verbo compreender (conter, abranger, incluir), dá a idéia da dispersão da corporeidade, que permite ao eulírico igualar-se de corpo e espírito à natureza englobante.

E a boca, aqui, continua a ser ladeada pela vegetalidade rumo à mineralidade, num apelo àquela situação já vista no poema anterior:

E o que foi música e sede de sarças Há de ser pasto de águas...

Tanto esta referência à dispersão na mineralidade quanto a ausência dos registros de limite do corpo remetem para o estado entre a dispersão caótica do eu-real originário, regido pela incorporação e anterior à introjeção, e a do euprazer/desprazer, em que este corpo real originário se remanejaria a partir de emblemas fálicos (Corpo em árvore feito/Serei como talha de pedra e ... os troncos rugosos/pendendo suas bocas para as águas). Se não é possível apontar que o eu-lírico figura para si uma unidade narcísica do corpo, o emblema fálico, necessário para tanto, permanece, talvez como resíduo, nas duas situações.

Pensamos que esta situação intermediária entre o eu-real originário e o eu-prazer/desprazer se inscreve na demanda regressiva, por representar um retorno na sucessão dos sistemas psíquicos, em relação ao eu-realidade definitivo, e sinalizar a recusa ao princípio de realidade.

Vejamos outro exemplo desta figuração do corpo: 
4.

Que rosa esplendente é o amor!

Que maravilha adorar!

Tenho certeza que ando perdida

E que o Senhor me perdoará.

Que fazer com o rosto de amora

No instante dele chegar?

Meus olhos negros de sonhos

Minha boca de beijar?

(No campo as árvores dormem

Banhadas em luz de luar...)

Meu corpo pra que me serve

Senão pra desabrochar

Entre as colinas noturnas

Na hora dele chegar? (p. 77)

A figura do símile, ao escolher-se a rosa como comparante, é um clichê literário dos mais surrados. Pretendemos, entre outras coisas, afirmar que a figura desgastada, na cadeia do poema em questão, recupera seu vigor, e se o consegue, é em parte pela existência desta demanda regressiva a que estamos frequientemente aludindo.

A segunda estrofe do poema já torna explícito o estado de desencontro do eu-lírico com o mundo, estando também sugerido que este desencontro ocasiona o sentimento de culpa e que tem sua origem na inquietação de ordem amorosa, introduzida pela estância anterior.

Em seguida, a predicação impertinente novamente se dá pela via da fusão do corpo (rosto) com elementos da vegetalidade (amora). A isotopia da vegetalidade será composta por rosa, amora, árvores e desabrochar. Em todas as ocorrências estas palavras estão, em menor ou maior grau, em situação de impertinência com elementos do corpo ou atividades humanas, como o amor. Se aqui é menos evidente o trabalho da demanda regressiva, ela pode, entretanto, ser desvelada ao associar a esta sutil indefinição morfológica do corpo a condição de imobilidade ou fixidez do mundo vegetal. Um componente potencializador e decisivo é a renúncia à ação, lapidar na idéia da espera pelo bem-amado. 
Esta espera é conhecida de longo tempo na nossa tradição literária. $\mathrm{O}$ discurso do eu-lírico parece ser claramente dirigido a um interlocutor que ou é genérico demais ou é a natureza indiferente, afastada da espacialidade do texto pelos parênteses que isolam a penúltima estrofe: as árvores que, no campo, dormem ao luar. Este contexto emoldurou, no início de nossas realizações poéticas, no berço ibérico, as cantigas de amigo trovadorescas. Mesmo a mulher que se entrega é um contraponto à figura nobre cantada nas cantigas de amor, sendo um elemento distintivo do gênero de cantiga trovadoresca, mas sobretudo, nestas condições, uma oposição que nos permite restabelecer o tempo remoto em que a língua ensaiava seus primeiros passos na direção da elaboração poética.

E é neste passado histórico-literário que a regressão logrou alcançar o reencontro do clichê com o seu sabor fresco e antigo de originalidade, salvo do travo de flor podre da metáfora senil que é o clichê.

Assim a demanda regressiva não só permite a busca de uma primitividade harmônica, livre dos conflitos do presente, como também se alia ao propósito explícito do autor de promover o "arejamento" das palavras, de salvar a língua da morte pelo clichê.

Esta negação do tempo presente, da subjetividade atual, do corpo realidade-definitivo, do qual a boca impertinente se tornou o ícone mais caro neste momento da poesia de Barros, encontra seu exemplo mais definitivo no poema transcrito a seguir e a cuja análise se seguirá a consideração do componente do masoquismo, que vislumbramos por trás desta deformação do corpo e da subjetivação madura, isto é, regida pelo princípio de realidade. $O$ poema não coincidentemente se chama "A boca".

\author{
A boca \\ Por mim passavas \\ - a água mais pura - \\ e eu sofri sede. \\ Agora penso \\ nessa abertura \\ com que por anos \\ me envenenaste, \\ com que por anos \\ a minha infância \\ tornaste impura, \\ tornaste indígna \\ de andar ao lado
}




\author{
de outras infâncias... \\ Agora penso \\ deixar na fenda \\ de tua boca, \\ dissimulada, \\ todo o veneno \\ de que inundas. \\ Porém és morta \\ resignada, \\ ó boca amarga \\ de namorada \\ nunca atingida, \\ sempre anelada, \\ boca perdida \\ para as saudades, \\ amais beijada. \\ Dorme entre flores. \\ (Será dos anjos?). \\ Vai para os anjos \\ vai para os pássaros \\ do firmamento, \\ ó boca amarga, \\ que me enganavas \\ com aquele riso \\ posto no canto! \\ Por mim passavas \\ - a água mais pura - \\ e eu sofri quanto. \\ Estás no seio \\ da morte, quente \\ como na terra; \\ me conturbavas \\ como na rua \\ tu exibias \\ teus belos dentes... \\ Vai grota rasa! \\ Flor obscura \\ na minha infância \\ desabrochada, \\ continuada \\ na adolescência \\ perto de casa, \\ na vizinhança,
}




\author{
solta na rua \\ como uma fruta \\ covil aberto \\ de mil acenos, \\ cobra na rua \\ que me mordia \\ que me injetava \\ sutis venenos... \\ Vai, pesadelo, \\ noites de insônia, \\ pura miragem \\ de minha sede; \\ vai para o diabo \\ que te carregue, \\ não me persiga: \\ sai, boca morta! (p. 91-93)
}

Estão aqui o sofrimento da privação - da satisfação orgânica (e eu sofri sede), da satisfação sexual (namorada nunca atingida), da satisfação do desejo de vingança (porém és morta) -; a recordação da infância, que é descrita como envenenada, impura; no plano formal, a impertinência com a indispensável isotopia da vegetalidade; a fantasia delirante (/pesadelo/, /vai grota rasa/, /não me persiga).

É de se notar a ruptura do corpo, através da qual, metonimicamente, a boca representa a totalidade do objeto perdido que o eu-lírico deseja, a todo custo, exorcizar de sua vida presente. Os verbos "passavas" $e$ "sofri" fixam pela repetição, nas estrofes paralelas, o sofrimento nascido no passado e prolongado até o presente da enunciação. Quase todas as formas verbais no passado, aliás, compõem uma isotopia do sofrimento: sofri, envenenaste, tornaste [impura, indigna], enganavas, conturbavas, mordia e injetava [sutis venenos]. As outras formas no pretérito unidas a esta isotopia do sofrimento formam uma isotopia do passado, que domina o texto e impõe a ênfase no desconforto vivido no presente.

Este presente de privações e insatisfações constitui um forte fator na determinação de uma regressão e o eu-lírico não encontra outra alternativa senão forjar um retorno. Esta tentativa de eliminar o sofrimento encontra no emprego do imperativo (vai, sai) uma ferramenta decisiva para ocultar a negação do desejo de restabelecer uma ordem harmônica, salvando o passado destas recordações negativas. O que o eu-lírico desejaria de fato é reconstituir o objeto amado e perdido num estatuto de pureza e satisfação, como bem nos insinuam 
os versos a água mais pura / com aquele riso / posto no canto!/ teus belos dentes/ flor obscura/ solta na rua / como uma fruta.

Na impossibilidade de exercer uma desejada onipotência de pensamento, de operar a transformação da história passada - ou de sua rememoração -, a única alternativa possível passa a ser a da renúncia ao princípio de realidade, que o levaria a construir uma outra escolha de objeto, pautada na possibilidade de vivência de satisfação. E é assim que o eu-lírico se deixa orientar por uma organização sádica que verbaliza o desejo de punição quando o que se quer exprimir é o desejo de satisfação do amor.

Encaixa-se aqui, com perfeição, o raciocínio de Freud sobre a regressão da libido, que extraímos da versão eletrônica de sua Conferência XXII - Algumas idéias sobre desenvolvimento e regressão:

Na neurose obsessiva, pelo contrário, é a própria regressão da libido ao estádio preliminar da organização sádico-anal o fato mais marcante e o fato decisivo para aquilo que se manifesta nos sintomas. A impulsão de amor, quando isto aconteceu, é obrigada a disfarçar-se em impulsão sádica. A idéia obsessiva "Eu gostaria de te matar", quando despojada de determinados acréscimos, não casuais, contudo indispensáveis, não significa, no fundo, outra coisa senão "Eu gostaria de me deleitar com amor"?

Pretendemos, através destas considerações que elegeram poemas deste Poesias, ter demonstrado o papel da regressão no discurso poético desta fase de Manoel de Barros, como resposta aos estímulos que ainda são de ordem externa. Mais adiante, sempre que necessário, retornaremos ao papel da regressão, evidenciando a mudança progressiva dos fatores que lhe servem de causa.

7 FREUD, S. Conferência XXII - algumas idéias sobre desenvolvimento e regressão. Edição Eletrônica Brasileira das Obras Psicológicas Completas de Sigmund Freud. Rio de Janeiro: Imago, 2000. 


\section{Quem balança o berço do masoquismo?}

Passemos agora à consideração do componente masoquista nesta quadra da produção poética barrosiana.

O soneto Viagem, forma fixa encravada entre poemas de estrofação livre, chama atenção não apenas por este detalhe da forma:

Rude vento noturno arrebatou-me

Para longe da terra, nu e impuro.

Perdi as mãos e em meio ao oceano escuro

Em desespero o vento abandonou-me.

Perdido, rosto de água e solidão, Adornei-me de mar e de desertos. Meu paletó de azuis rasgões abertos

Esconde amanhecer e maldição...

Um deserto menino me acompanha

$\mathrm{Na}$ viagem (que flores deste caos!)

E em rosa o sol me veste e me inaugura.

Dou às praias de Deus: a alma ferida,

As mãos envenenadas de ternuras

E um buquê de carnes corrompidas.(p. 100)

Não parece se tratar de um poema de alguém que diria mais tarde, no "Arranjos para assobio" (1982): "A partir do inominado/ e do insignificante/ é que eu canto". ${ }^{8}$ Estamos ainda distantes do Compêndio para uso dos pássaros (1961), no qual o verso infantilizado passa a ser a tônica da lírica barrosiana. Convém, entretanto, lembrar que já é de 1956 o magnífico Encontro de Pedro com o nojo, exemplar no exercício da adjetivação inusitada, na incoerência enquanto dinâmica mental e também na representação literária da condição de desamparo.

A verbalização metaforizada da morte, ou, mais apropriadamente, do desejo/medo em relação à morte, corresponde a um primeiro nível de elaboração discursiva do eu-lírico. É possível desvendar a existência e a lógica de um outro

8 BARROS, op. cit., p. 214. 
nível, mais importante. Descartemos, por ora, a tentação de algumas leituras "explicativas", mas que não permitiriam ligar o discurso do eu-lírico à sua condição desamparada e pré-infantilizada.

Um primeiro nível de leitura não descartaria as marcas superficiais do texto, que convidam a uma interpretação ou redução da metáfora da morte, que parece ser o essencial do poema.

A facilidade associativa que o título do soneto permite, bem como a isotopia da /desordem/ - que aponta para a deterioração do ser, marcada por rasgão, perdi, desespero, caos, perdido, ferida e corrompidas - convidam o leitor a aceitar o jogo associativo e a reduzir o poema a uma dimensão puramente alegórica. Seria uma página de melancolia ou, por amor da precisão, de contemplação da tristeza ou da morte. Estariam lá a assonância do /u/ na primeira e os fonemas nasais em todas as estrofes para reforçar, a partir do plano formal, a evocação deste estado de tristeza.

Mas, de onde viria este sentimento? Devería-se atribuí-lo tão somente a uma "consciência de desvalimento" (Em desespero o vento abandonou-me) proveniente da constatação da finitude e brevidade da vida humana? Ou seria mero reflexo de algum evento da sua experiência anterior cujo conhecimento nos teria sido negado? Sabemos, porém, que o estado de desamparo, na condição de destino vocacional do ser humano, não está necessariamente a depender de uma percepção em nível consciente ou pré-consciente. Sabemos também que a simples postulação de um evento experiencial anterior ao momento da enunciação, refletindo sobre o eu-lírico, é de caráter tão genérico que pouco ajudaria na investigação das motivações do eu-lírico tomado enquanto sujeito. Podemos afirmar, pois, tendo em mente essas possibilidades, que nenhuma delas permite verticalizar, com segurança, a relação entre o discurso e a dinâmica pulsional.

Porém, longe de ser um exercício de conceituação poética da morte, distorcida ou não pelo medo (Angst), a matriz que nos dá a chave interpretativa é outra e não tem vínculo com as associações habilmente conduzidas pelo eulírico a partir da pista falsa que é o título do poema.

No soneto, a irrupção da culpa é observável e levada, ao que parece, pré-conscientemente. Posto que o discurso elaborado contém uma isotopia da "culpa" - cujo traço semântico comum está contido em nu, impuro, esconde, maldição, carnes e corrompidas - em relação com uma isotopia da "punição" - 
arrebatou-me, desespero, abandonou-me, rasgões, feridas e envenenadas - impõe-se a consideração dos componentes masoquistas ${ }^{9}$ de sua verbalização.

Fosse o caso do masoquismo moral, podería se afirmar, segundo Freud, que na base desta representação de afeto em relação a morrer, estaria aquela situação em que

...o masoquismo cria uma tentação a efetuar ações 'pecaminosas', que devem então ser expiadas pelas censuras da consciência sádica (como é exemplificado em tantos tipos caracterológicos russos) ou pelo castigo do grande poder parental do Destino. A fim de provocar a punição desse último representante dos pais, 0 masoquista deve fazer o que é desaconselhável, agir contra seus próprios interesses, arruinar as perspectivas que se abrem para ele no mundo real e, talvez, destruir sua própria existência real. ${ }^{10}$

Não é o caso: não se pode falar em masoquismo moral senão quando o sentimento de culpa é inconsciente, ou, como escreve Freud, quando há "necessidade de punição". Agora o problema é situar: onde está e qual é, então, o componente masoquista fundante do poema?

Ele está por trás de uma isotopia que permite explicitar a fantasia masoquista, a isotopia do "espancamento": rasgão, perdi, ferida e corrompidas. É então do masoquismo feminino que se fala. E o outro nível a que aludiu-se, no início das considerações sobre o soneto, seria o da fantasia do espancamento.

Evidente está que, enquanto representação literária, esta fantasia difere dos relatos e das condições que permitiram a Freud a elaboração de suas considerações no estudo sobre a questão econômica do masoquismo. Veja-se, por hora, algumas conclusões de Freud sobre o masoquismo feminino:

9 Aqui e para isto convem lembrar que Freud demonstra que o masoquismo - ao contrário do que ele afirmara antes de conceber a existência da pulsão de morte - nāo deriva necessariamente de um sadismo anterior. Este masoquismo primário ou "erógeno" conduziria a duas formas derivadas. A que ele chama de feminina é estudada em "Ein Kind wird geschlagen" - Uma crianf̧a é espancada (1919). A outra forma, o masoquismo moral, permitirá que Freud desvende alguns novos problemas em vinculação com sentimentos de culpa e o funcionamento da consciência.

10 Ver "O Problema econômico do masoquismo". Cf. FREUD, op. cit. 
A interpretação óbvia, à qual facilmente se chega, é que o masoquista deseja ser tratado como uma criança pequena e desamparada, mas, particularmente, como uma criança travessa.

Por essa razão chamei essa forma de masoquismo, a fortiori por assim dizer [isto é, com base em seus exemplos extremos], de forma feminina, embora tantas de suas características apontem para a vida infantil. Essa estratificação superposta do infantil e do feminino encontrará posteriormente uma explicação simples. Ser castrado - ou ser cegado, que o representa - com freqüência deixa um traço negativo de si próprio nas fantasias, na condição de que nenhum dano deve ocorrer precisamente aos órgãos genitais ou aos olhos. (As torturas masoquistas, incidentalmente, com raridade, causam uma impressão tão séria quanto as crueldades do sadismo, quer imaginado ou realizado.) Também um sentimento de culpa encontra expressão no conteúdo manifesto das fantasias masoquistas; o indivíduo presume que cometeu algum crime (cuja natureza é deixada indefinida), a ser expiado por todos aqueles procedimentos penosos e atormentadores. Isso se parece com uma racionalização superficial do tema geral masoquista, mas jaz por trás dela uma vinculação à masturbação infantil. Por outro lado, esse fator de culpa fornece uma transição para a terceira forma de masoquismo, a moral.

Conclui-se que, para confirmar a fantasia de espancamento, construída a partir do masoquismo feminino (ou infantil) engendrado pelo sentimento de culpa e pelo desejo de ser castigado para expiar um presumível crime, pouco mais se torna necessário: a identificação de resíduos do trabalho do recalque que, por sua vez, possam provar a identificação do eu-lírico com uma criança travessa que deve ser punida por este substituto parental que é o destino. Também cumpre constatar o mecanismo de castração, que deixaria o traço negativo de si próprio nas fantasias do eu-lírico.

O primeiro elemento é identificável a partir do desvendamento de uma isotopia do "começo", associada a uma isotopia da "infância": menino, inaugura, amanhecer. Cumpre-se então a presença de resíduos que permitam, embora parcialmente, afirmar "No começo, na infância, fui mau e devo ser punido". As mãos perdidas e mais tarde recuperadas representam a fantasia da castração. 
Freud inicia o ensaio $O$ problema econômico do masoquismo afirmando que "a existência de uma tendência masoquista na vida instintual dos seres humanos pode corretamente ser descrita como misteriosa desde o ponto de vista econômico. Pois se os processos mentais são governados pelo princípio de prazer de modo tal que o seu primeiro objetivo é a evitação do desprazer e a obtenção do prazer, o masoquismo é incompreensível".

Mas ao situar que o princípio de Nirvana expressa a tendência do instinto de morte; o princípio de prazer representa as exigências da libido, e o princípio de realidade representa a influência do mundo externo, Freud esclarece que nenhum destes princípios exclui o outro, embora possam provir conflitos desta tolerância mútua. Admitindo que há um estado em que a pulsão de morte ainda é voltada contra o próprio sujeito, e admitindo ainda a possibilidade de uma inversão da atividade em passividade, compreenderemos como Freud chega à idéia de que, por meio de uma fantasia vincada pela identificação, o sujeito possa fazer com que um estranho lhe inflija dor. Pela identificação, o ego passivo se coloca fantasisticamente na posição do Outro, que foi a sua posição anterior.

Convém lembrar que na fase mítica em que a pulsão de morte está toda voltada contra o indivíduo, está também ligada à libido e unida a ela. A libido deriva para o mundo exterior grande parte da pulsão de morte. A parte restante "não acompanha este desvio para o exterior, permanece no organismo onde é ligada libidinalmente com a ajuda da excitação sexual que a acompanha (...); reconhecemos aqui o masoquismo originário, erógeno."

Freud distingue, entretanto, três formas de masoquismo:

O masoquismo apresenta-se à nossa observação sob três formas: como condição imposta à excitação sexual, como expressão da natureza feminina e como norma de comportamento (behaviour). Podemos, por conseguinte, distinguir um masoquismo erógeno, um masoquismo feminino e um masoquismo moral.

Sobre o masoquismo feminino, Freud afirma:

Havendo, porém, uma oportunidade de estudar casos em que as fantasias masoquistas foram, de modo especial, ricamente elaboradas, de imediato se descobre que elas colocam o indivíduo numa 
situação caracteristicamente feminina; elas significam, assim, ser castrado, ou ser copulado, ou dar à luz um bebê. Por essa razão chamei essa forma de masoquismo, a fortiori por assim dizer [isto é, com base em seus exemplos extremos], de forma feminina, embora tantas de suas características apontem para a vida infantil.

Sobre o masoquismo moral, esta forma "foi identificada pela psicanálise como um sentimento de culpa que, na maior parte, é inconsciente." Para detalhamento deste tipo, convém rever os conceitos de necessidade de punição, sentimento de culpa, superego, entre outros.

A feminilidade e o masoquismo são compreendidos na visão que expomos, como formas de proteção contra a experiência insuportável do desamparo. O masoquista, segundo Birman, parece dizer "Goze com o meu corpo e faça com ele o que bem entenda, me humilhe como quiser, mas fique comigo e não me abandone sozinho no meu desamparo". O masoquismo moral e o masoquismo feminino, desta forma, através da figura do algoz, valorizam a figura do falo. Éo horror da desfalização que os conduz, na busca desesperada por proteção.

Mas o masoquismo erógeno suspende o referencial fálico. Ele pertence àquele estado anterior ao retorno do sadismo sobre o sujeito. É a suspensão do referencial fálico e a busca de novas formas de relação do sujeito consigo mesmo e com o Outro.

Note-se o que diz Birman sobre a feminilidade:

Enquanto pelo falo o sujeito busca a totalização, a universalidade e o domínio das coisas e dos outros, pela feminilidade o que está em pauta é uma postura voltada para o particular, o relativo e o não-controle das coisas. Por isso mesmo a feminilidade implica a singularidade do sujeito e as suas escolhas específicas, bem distantes da homogeneidade da postura fálica. A feminilidade é o correlato de uma postura heterogênea que marca a diferença de um sujeito em relação a qualquer outro. ${ }^{11}$

11 BIRMAN, J. Cartografias do feminino. São Paulo: Ed. 34, 1999. p. 10. 
Primeiramente, o estado de desamparo é a condição resultante do impacto das pulsões e de seus representantes sobre o indivíduo, além da dependência do Outro, que lhe nomeará os objetos necessários à sua satisfação. $O$ masoquismo feminino e o masoquismo moral são vistos como formas de proteção contra o desamparo, regidas pela possibilidade de totalização e apaziguamento oferecidas pela (im)postura fálica. E a feminilidade, na sua relação com o masoquismo erógeno, a forma de o sujeito construir novos destinos e marcar uma individuação radical, na suspensão do referencial fálico.

O eu-lírico barrosiano, monoliticamente uniforme na expressão da condição de desamparo, estrutura a sua subjetivação pela recusa do masoquismo feminino e do masoquismo moral, orientando-se para a negação do papel unificador dos emblemas fálicos. Neste masoquismo erógeno, a imagem do corpo será violentamente marcada por uma dinâmica de dispersão caótica. Aqui, no início deste percurso, ainda encontram-se traços de um masoquismo feminino nesta fantasia de espancamento, mas, ao progredir na internalização formal da demanda regressiva, esta recusa dos emblemas fálicos - que organizam e conferem universalidade ao mundo - passará a se servir unicamente da própria linguagem. O conteúdo da infância - e de suas formas de desenvolvimento ainda não desabrochadas plenamente - marcará a forma da expressão, permitindo prescindir de estratégias como a que acabamos de demonstrar no soneto analisado.

\section{Demanda regressiva: traço evolutivo da dicção barrosiana}

No conjunto que destacado como pertencendo a um primeiro momento da poesia de Manoel de Barros, os livros Poemas concebidos sem pecados (1937) e Face imóvel (1942) configuram um quadro de elaboração artística bem diverso do que se inaugura com Poesias (1956). O primeiro é marcado por uma inventividade formal bem ao gosto das primeiras obras modernistas em nossas letras, mas ainda não há em Poemas concebidos sem pecado um conjunto de procedimentos formais verdadeiramente capaz de individualizar um estilo barrosiano.

Do ponto de vista do que temos chamado subjetivação do eu-lírico, não se observa ainda a demanda regressiva. A infância é conteúdo e cenário da enunciação poética, mas o eu-lírico unifica sua subjetividade enquanto adulto.

O livro seguinte, Face imóvel, já está mais próximo do estilo que tornou conhecida a poesia de Manoel de Barros. Não se pode falar de estilo maduro 
sem sentir um suave perfume de paradoxo, já que, quanto mais amadurece o poeta, mais o estilo figura com perfeição a dicção renovada das crianças. Chama a atenção o fato de que o eu-lírico agora não mais manifesta inclinações contraditórias entre si. O mecanismo da evitação da ação produz, de fato, um efeito de unificação do eu-lírico, presente na maioria esmagadora dos dezessete poemas.

Todavia, a grandeza com que Barros consegue dar tratamento ao seu conteúdo naquele momento também não atinge a radicalidade que alcançará quando o conteúdo tratado passa a determinar os elementos de estilo. Isto é visivel a partir de Poesias.

A característica fundamental desta fusão entre conteúdo e estilo é traçada pelo tema do corpo, através do qual começa a se delinear um movimento de retorno a estágios de desenvolvimento anteriores. Esta tensão ainda se exprime pela oposição entre o adulto e a criança, mas sua existência é suficiente para eliminar o efeito de evidência nos temas escolhidos.

\section{RESUMO}

Abordagem da poesia de Manoel de Barros que reflete sobre a representação do sujeito na expressão de sua condição desamparada e sobre como esta estratégia de construção poemática é conseguida através do abandono da representação de um funcionamento mental mais elaborado, em benefício de uma demanda regressiva, que lhe define o estilo da poesia madura.

Palavra-chave: desamparo, poesia, psicanálise.

\section{RÉSUMÉ}

Ce travail reconstitue le parcours de la discussion sur les analogies et les différences entre les récits fictionnel et historique dans les trois dernières décennies du $\mathrm{XX}^{\mathrm{im}}$ Siècle, période décisive pour cette problématique, dans le but d'affiner quelques stratégies d'analyse des oeuvres de fiction historique.

Mots-clef: fiction et histoire; fiction historique. 


\section{REFERÊNCIAS}

BARROS, M. de. Gramática expositiva do chão: (poesia quase toda). 3. ed. Rio de Janeiro: Civilização Brasileira, 1996.

BIRMAN, J. Cartografias do feminino. São Paulo: Ed. 34, 1999.

FREUD, S. Reflexões para os tempos de guerra e morte. In: FREUD, S. A História do movimento psicanalítico, artigos sobre metapsicologia e outros trabalhos. Rio de Janeiro: Imago, 1996. Edição Standard Brasileira das Obras Psicológicas Completas de Sigmund Freud, v. 14, p. 282-312.

FREUD, S. O problema econômico do masoquismo. In: EDIÇÃO Eletrônica Brasileira das Obras Completas Psicológicas de Sigmund Freud. São Paulo: Imago, 2000. 1 CDROM.

FREUD, S. Uma criança é espancada. In: EDIÇÃO Eletrônica Brasileira das Obras Completas Psicológicas de Sigmund Freud. São Paulo: Imago, 2000. 1 CD-ROM.

LAPLANCHE, J.; PONTALIS, J.-B. Vocabulário da psicanálise. 3. ed. São Paulo: Martins Fontes, 1998. 